\title{
Ukuran Perusahaan, Profitabilitas, Likuiditas dan Pengungkapan Tanggungjawab Sosial
}

\author{
Ni Nyoman Desi Antari ${ }^{1}$ \\ Fakultas Ekonomi dan Bisnis \\ Universitas Udayana, Indonesia
}

\author{
Ni Gusti Putu Wirawati² \\ Fakultas Ekonomi dan Bisnis \\ Universitas Udayana, Indonesia
}

\begin{abstract}
Surel : desiantari253@gmail.com
ABSTRAK

Riset ini dilakukan untuk memperoleh bukti empiris mengenai pengaruh ukuran perusahaan, profitabilitas, dan likuiditasi pada Corporate Social Responsibility Disclosure perusahaan terkategori high profile yang terdaftar di BEI tahun 2015-2018.Hasil penelitian ini menunjukkani bahwa CSR Disclosure dipengaruhii oleh ukuran perusahaan, namun tidak dipengaruhi ooleh profitabilitas dan likuiditas. Penelitiana ini memberi implikasi kebijakan praktis bagi perusahaan, dimana kebijakan yang dilakukan perusahaan harus memberikan perhatian yang seimbang bagi seluruh komponenn yang terlibat langsung nmaupun tidak di dalam jalannya kegiatan usaha perusahaan. Implikasi penelitian lebih lanjut dapat dipergunakan sebagai referensi dalam mengambil.keputusan.terkait investasi.
\end{abstract}

Kata Kunci: $\quad$ CSR Disclosure; Ukuran Perusahaan; Profitabilitas; Likuiditas High Profile.

\section{Company Size, Profitability, and Liquidity and Corporate Social Responsibility Disclosure}

\section{ABSTRACT}

This research was conducted to obtain empirical evidence about the influence of company size, profitability, and liquidity on the Corporate Social Responsibility Disclosure of high profile companies that listed on the Indonesian Stock Exchange in 2015-2018. The results of this research indicate that CSR Disclosure eis influenced by company size, but not influenced by profitability and liquidity. This research has practical policy implications for companies, where the policies of the company must provide balanced attention to all components directly or indirectly involved in the course of the company's business activities. The implications of further research can be used as a reference in making investment-related decisions.

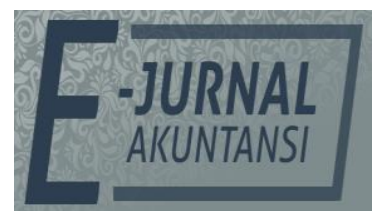

e-ISSN 2302-8556

Vol. 30 No. 11

Denpasar, Nopember 2020

Hal. 2810-2824

DOI:

10.24843/EJA.2020.v30.i11.p08

PENGUTIPAN:

Antari, N.N.D. \& Wirawati, N.G.P. (2020). Ukuran Perusahaan, Profitabilitas,

Likuiditas dan

Pengungkapan

Tanggungjawab Sosial. EJurnal Akuntansi, 30(11), 2810-2824

RIWAYAT ARTIKEL:

Artikel Masuk:

1 Februari 2020 Artikel Diterima: 22 Juli 2020

Keywords: CSR Disclosure; Company Size; Profitability; Liquidity; High Profile.

Artikel dapat diakses : https://ojs.unud.ac.id/index.php/Akuntansi/index 


\section{PENDAHULUAN}

Perkembangan zaman serta kemajuan ilmu pengetahuan dan teknologi, menuntun masyarakat untuk tidak hanya memikirkan bagaimana memperoleh keuntungan yang maksimum, namun juga melihat kondisi lingkungan hidup. Setiap kegiatan usaha pasti menimbulkan dampak bagi masyarakat di luar perusahaan, oleh karena itu perusahaan didorong untuk membentuk divisi tanggung jawabn sosial perusahaan atau Corporate Social Responsibility (CSR). Program tanggung jawab sosial atau CSR ini dibentuk sebagai upaya untuk mengurangi risiko dan tuduhan terhadap perusahaan apabila dianggap melakukan perilaku tidak pantas bagi lingkungan sekitarnya.

Berbagai kasus pencemaran lingkungan akibat kelalaian aktivitas perusahaan pernah terjadi di Indonesia. Kasus PT. Lapindo Brantas adalah salah satu yang belum terselesaikan hingga kini. PT. Lapindo Brantas harus menanggung konsekuensi atas kerugian yang diakibatkan oleh kelalaian aktivitas operasionalnya yang menyebabkan adanya semburan lumpur panas yang menenggelamkan beberapa kecamatan di Jawa Timur. Kasus PT. Freeport di Papua juga merupakan salah satu kasus kecelakaan tambang terbesar di Indonesia, dimana menurut penyelidikan dari Komnas HAM, PT. Freeport telah melanggar hak asasi manusia yang menyebabkan tewasnya puluhan pekerja tambang. Area tambang Big Gossan yang runtuh telah diselidiki dan ditemukan bukti bahwa PT. Freeport lalai dalam melakukan pengawasan secara langsung di area tambang. Kasus kebakaran hutan yang tahun ini kembali terjadi di daerah Sumatra dan Kalimantan juga diduga kuat merupakan akibat kelalaian salah satu perusahaan sawit dalam mengawasi lahan mereka. Kasus-kasus tersebut harus menjadi cerminan bagi semua pihak, utamanya bagi perusahan agar kedepannya tidak terjadi lagi.

Adanya sanksi bagi usahawan yang lengah dalam menjaga keamanan warga bahkan menyebabkan kematian bagi pengguna produk atau jasanya membuktikan bahwa CSR telah ada sejak dahulu. Tonggak sejarah CSR modern adalah karya dari Horward Bowen yang berjudul Social Responsibilities of the Businessman yang diterbitkan tahun 1953. Bowen (195) menerangkan bahwa dengann tanggung jawab sosial, perusahaan memiliki kewajiban melaksanakan kebijakan, keputusan, atau untuk menjalankan norma yang sesuai dengan yang ada dalam tujuan juga nilai-nilai yang tertanam di masyarakat.

Sejak 1960-an, baik beasiswa dan praktik CSR telah berkembang secara eksponensial, dan perempuan menjadi lebih terlihat dalam bisnis (Caulkins et al., 2013). Pertumbuhan CSR di tahun 1990-an sampai sekarang ini adalah konsekuensi dari diperkenalkannya konsepsi sustainable development yang menstimulasi kemunculan sustainability report dengan triple bottom line, yaitu profit (produksi barang dan jasa), people(dampak keamasyarakat di dalam maupun di luar perusahaan), dan planet (dampak terhadap lingkungan alam), yang digagas oleh Elkington (1997).

Konsep CSR berkembang hingga saat ini dipengaruhi juga oleh penyesuaian tujuan CSR, yang tadinya bersifat sukarela (voluntary) yang tidak ada sangkut pautnya dengan strategi dan tujuan jangka panjang, menjadi suatu kegiatan strategis yang memiliki keterkaitan dengan strategi dan tujuan jangka panjang perseroan. Perseroan diharuskan untuk siap mempertanggungjawabkan 
seluruh aktivitas operasi dalam tujuan mendapat profit dengan mengimplementasikan program CSR. UU PT. No. 40 tahun 2007 menyatakan Tanggung Jawab Sosial dan Lingkungan merupakan komitmen perusahaan untuk ikut berpartisipasi dalam pembangunan ekonomi berkelanjutan guna meningkatkan kualitas kehidupan dan lingkungan yang bermanfaat, baik bagi perseroan sendiri, komunitas setempat, maupun masyarakat pada umumnya. Ada dua sifat dalam pengungkapan CSR, yaitu voluntary disclosures dan mandatory disclosure. Voluntary Ddisclosure adalah pengungkapan yang bersifat sukarela yang dilaksanakan oleh perusahaan serta tidak ada patokan yang mengikat dalam pengungkapan tersebut. Mandatory disclosure merupakan pengungkapan yang bersifat mengikat dilaksanakan perusahaan karena adanya peraturan mengikat yang mengisyaratkan perusahaan untuk melakukan pengungkapan tersebut. Pengungkapan yang bersifat wajib (mandatory) merupakan pengungkapan minimal yang sesuai dengan syarat badan berwenang (Pemerintah, IAI, maupun BAPEPAM-LK).

Praktik CSR di Indonesia diatur poleh UU No. 40 Tahun 2007, dimana Pasal 74 ayat (1) tentangg Perseroan Terbatas mengatur bahwa perseroan yang menjalankan kegiatan usahanya di bidang dan/atau berkaitan dengan sumber daya alam wajib melakukan tanggung jawab sosial dan lingkungan, kemudian dalam ayat (2) mengatur bahwa tanggung jawab sosial dan lingkungan merupakan kewajiban perseroang yang dianggarkan dan diperhitungkan sebagai biaya perseroan yang pelaksanaannya dilakukan dengan memerhatikan kepatutan dan kewajaran, sedangkan ayat (3) mengatur bahwa perseroan yang tidak melaksanakan kewajiban tersebut dapa dipidana. Peraturan Pemerintah No. Tahun 2012 pasal 2 juga menjelaskan bahwa setiap perseroan selaku subjek hukum mempunyai tanggung jawab sosial dan lingkungan. Peraturan BAPEPAM LK No. X.K.6 Tahun 2012 tentang kewajiban penyampaian laporan tahunan emiten atau perusahaan publik mengatur bahwa annuals reports emiten atau perusahaan publik wajib memuat mengenai tanggung jawab sosial perusahaan.

Berdasarkan teori stakeholder, pengungkapan tanggung jawab sosial perusahaan yang dimuat dalam annual report mencerminkan bahwa perusahaan telah memenuhi tanggung jawabnya atas harapan masyarakat yang menginginkan perusahaan melaksanakan kegiatan yang memberikan manfaat bagi semua elemen yang ada di sekitarnya. Pengungkapan CSR dalam annual report juga menunjukkan bahwa perusahaan telah menyesuaikan diri dan taat dengan peraturan yang telah berlaku. Ketaatan perusahaan terhadap peraturan yang berlaku akan memeroleh atensi positif dari masyarakat dan dapat menjamin keberlangsungan hidup perusahaan. Penjelasan tersebut sesuai dengan yang terdapat dalam teori legitimasi, dimana perseroan secara berkesinambungan berusaha untuk berperan sesuai dengan norma yang valid di masyarakat.

Roberts (1992), dalam tulisannya yang berjudul "Determinants of Corporate Social Responsibility Disclosure: An Application of Stakeholder Theory", menyatakan terdapat 2 (dua) tipe perseroan, dimana yang pertama adalah high profile dan yang kedua adalah low profile. Perseroan highp profile merupakan perusahaan yang banyak bersinggungan dengan alam dan menimbulkan residu dalam 
kegiatan usahanya. Perbedaan mendasar antara perseroan terkategori high profile dengan low profile dalam mengungkapkan tanggung jawab sosial perusahaannya adalah perseroan dengan kategori high profile lebih banyak mengemukakan bermacam aktivitas perusahaan, khususnya terpaut masalah sosial dan lingkungan. Aktivitas usaha perseroan terkategori high profile (misalnya usaha tambang), dipandang memiliki efek yang lebih riskan bagi lingkungan dan sosial (Widiastuti et al., 2018).

Arika \& Sudana (2017) mengklasifikasikan perusahaan yang termasuk ke dalam kategori high profile adalah industri minyak dan tambang, industri dasar dan kimia, makanan dan minuman, otomotif dan komponen, pertanian dan perikanan, industri rokok, media dan komunikasi, transportasi serta pariwisata. Widiastuti et al., (2018) dalam penelitiannya mengkategorikan perusahaan minyak dan tambang, industri farmasi, indistri kehutanan, dan usaha transportasi sebagai perusahaan terkategori high profile.

Setiap jenis industri memiliki aktivitas pengungkapan CSR yang bervariasi. Pengungkapan CSR yang beragam mengindikasikan bahwa dalam praktik CSR yang dilakukan perusahaan masih terdapat variasi. Salah satu variabel yang dapat memengaruhi pengungkapan CSR adalah ukuran perusahaan. Pengungkapan CSR di industri besar akan jauh lebih luas dibandingkan dengan industri kecil. Ukuran perusahaan menunjukkan besar kecilnya suatu perusahaan yang dapat dilihat dari total aset. Praktik pengungkapan CSR memegang peranan penting bagi perusahaan, karena perusahaan hidup dalam lingkungan masyarakat dan tak jarang aktivitas perusahaan memiliki dampak sosial dan lingkungan. Ukuran perusahaan yang besar akan semakin membuat perusahaan dipandang oleh pembuat kebijakan, media, organisasi non pemerintah, dani masyarakat sehingga tekanan yang didapatkan akan lebih besar daripada yang dihadapi oleh perusahaan kecil. Industri yang berukuran besar cenderung melaksanakan kegiatan operasi yang lebih kompleks, berdampak lebih besar pada masyarakat, mempunyai lebih banyak shareholder, dan juga memeroleh atensi lebih dari publik, maka industri yang dikategorikan besar memeroleh lebih banyak tekanan dalam aspek pengungkapan tanggung jawab sosial.

Penelitian mengenai pengaruh ukuran perusahaan pada pengungkapan CSR membuahkan hasil yang berbeda. Razak (2015), Indraswari \& Astika (2015) serta Trencansky et al., (2014) mengungkapkan bahwa variabel ukuran perusahaan berpengaruh positif pada pengungkapan CSR. Namun penelitian yang dilakukan oleh Urmila \& Mertha (2017) serta Mandaika \& Salim (2015) menyatakan bahwa ukuran perusahaan tidak berpengaruh pada pengungkapan CSR.

Selain ukuran perusahaan, faktor lainnya yang dapat memengaruhi pengungkapan CSR adalah profitabilitas. Profitabilitas menunjukkan kapabilitas perusahaan dalam memeroleh keuntungan atau dapat diartikan pula sebagai ukuran keefektifan tata kelola manajemen perusahaan (Wiagustini, 2014:86). Perusahaan yang menghasilkan profit akan mampu memberikan deviden bagi pemegang sahamnya, mengalokasikan sejumlah profit yang didapat untuk pembiayaan keberlanjutan usaha perseroan, dan juga untuk pembayaran pajak kepada pemerintah. Perusahaan juga dapat turut serta dalam hal program 
pelestarian lingkungan untuk mewujudkan terpeliharanya kualitas kehidupan umat manusia dalam jangka panjang. Wujud perhatian bagi masyarakat dapat diberikan melalui pelaksanaan berbagai aktivitas sosial serta meningkatkan program pengembangan kompetensi bagi masyarakat. Perseroan dapat berkontribusi berupa sokongan dana, penyediaan tenaga ahli dari perusahaan, bantuan berupa barang, dan lain sebagainya.

Penelitian sebelumnya mengenai pengaruh profitabilitas pada pengungkapan CSR menunjukkan hasili yang berbeda. Kansal et al., (2014), Razak (2015), serta Urmila \& Mertha (2017) menyatakan bahwa profitabilitas memiliki pengaruh pada pengungkapan CSR. Namun Wuttichindanon (2017) menyatakan bahwa pengungkapan CSR dilakukan oleh perusahaan atas pengaruh pemangku kepentingan, bukan berdasarkan tingkat profitabilitas. Chek et al., (2013) dalam penelitiannya justru mengungkapkan bahwa profitabilitas yang diproksikan dengan return on asset hampir tidak memiliki pengaruh pada pengungkapan CSR.

Selain ukuran perusahaan dan profitabilitas, faktor selanjutnya yang dapat memengaruhi pengungkapan CSR adalah likuiditas. Likuiditas adalah suatu kondisi yang menunjukan kemampuan perusahaan dalam mendanai operasional perusahaan dan melunasi hutang jangka pendeknya (Wiagustini, 2014:85). Rasio dini digunakanu untuk memberikan gambaran mengenaih pengaruhh ketersediaan danan perusahaanm terhadap pengungkapan CSR. Likuiditas yang dimiliki oleh perusahaan dapat memengaruhi perusahaan dalam menjalankan tanggung jawab sosialnya terhadap lingkungan (Dewi \& Wirawati, 2017). Tingkat likuiditas biasanya dijadikan ssebagai tolak ukur dalamn pengambilan keputusan oleh pihak sstakeholder. Perusahaan yang sehat secara finansial akan lebih banyak mengungkapkan informasi mengenai praktik CSR perusahaan dibandingkan dengan perusahaan yang memiliki tingkat likuiditas rendah. Perusahaan yang memiliki likuiditas yang rendah akan mempersulit perusahaan dalam mendapatkan kepercayaaan untuk melakukan pinjaman dana, namun perusahaan yang tergolong memiliki likuiditas yang tinggi juga kurang baik, sebab terdapat banyak dana yang menganggur yang berdampak kepada mengecilnya profitabilitas perusahaan.

Penelitian sebelumnya mengenai pengaruh likuiditas pada pengungkapan CSR menemukan hasil yang berbeda. Putri et al., (2017), Dewi \& Wirawati (2017), Mudjiyanti \& Maulani (2017), serta Arif \& Wawo (2016) dalam penelitiannya menemukanj bahwap likuiditas yang ditunjukkan dengan Currentp Ratio terbukti memengaruhi pengungkapan CSR. Namun hasil berbeda diperoleh Rokhman (2015) yang menyatakan likuiditas tidak berpengaruh pada pengungkapan CSR, dimana dengan tingkat current ratio yang tinggi maka belumo tentu perusahaan dapat membayar kewajiban jangka pendeknya, sehinggad level pengungkapan CSR yang dilakukan semakin sedikit. Begitu pula dengan penelitian Agustin (2018) yang menyatakan bahwa likuiditas tidaki berpengaruhi terhadap pengungkapan CSR yang berarti perusahaan tidak melihat seberapa besar likuiditas ketika melakukan pengungkapan CSR karena telah ada regulasi yang mengikat perusahaan untuk wajib melaksanakan program CSR. 
Ukuran perusahaan menggambarkan besar kecilnya suatu perusahaan yang dapat dilihat dari total aset, jumlah penjualan, rata-rata total penjualan dan rata-rata total aset. Perusahaan besar tidak akan lepas dari tekanan pemegang saham untuk mengungkapkan pertanggungjawaban sosial sebab perusahaan besar dengan aktivitas operasi dan pengaruhi yang lebih besar terhadap masyarakat akan selalu diperhatikan oleh stakeholdernya dan pengungkapan CSR akan menunjang perusahaan dalam aspek penghindaran terhadap perselisihan dengan masyarakat.

Teori legitimasi menyatakan perusahaan yang besar aktivitasnya akan lebih terlihat daripada perusahaan yang kecil sehingga berbagai tuntutan dan tekanan dari masyarakats akan lebih besar. Penjelasan teori ini sesuai dengan apa yang diungkap dalam penelitian oleh Razak (2015), Yanti \& Budiasih (2016), Indraswari \& Astika (2015) serta Trencansky et al., (2014) yang menyatakan bahwa wukuran perusahaan berpengaruhi pada pengungkapan CSR. Berdasarkan uraian maka hipotesis yang diajukani dalama penelitiana ini sebagai berikut.

$\mathrm{H}_{1}$ : Ukuran perusahaan berpengaruh positif pada CSR Disclosure.

Menurut teori stakeholder, perusahaan mengemban tanggung jawab atas pemegang saham, komunitas sosial dan lingkungan sekitar perusahaan. Stakeholder mempunyai harapan dimana ketika perseroan mendapatkan laba, maka perusahaan diharapkan dapat memberikan kontribusi positif dalam sebuah kegiatan sosial dan mengungkapkannya dengan transparan dalam annual reports yang diterbitkan.

Perusahaan merupakan pihak yang memperoleh keuntungan dari adanya pemanfaatan terhadap suatu sumber daya, sedangkan masyarakat merupakan pihak yang menanggung dampak negative dari pemanfaatan sumber daya tersebut. Oleh karena itu, perusahaan harus mengembalikan sebagian keuntungan yang diperoleh untuk kesejahteraan masyarakat, perbaikan kerusakan yang ditimbulkan, dan lain-lain (Purwanto, 2011). Perusahaan yang tingkat profitabilitas tinggi cenderung untuk mengungkapkan lebih banyak informasi tanggung jawab sosial perusahaan tersebut, karena perusahaang yang memiliki kemampuan menghasilkan laba yang tinggi, biasanya juga memilikii banyak dana, termasuk untuk melakukan pengungkapan tanggunggjawab sosial, agar bisa mengurangi tekanan sosial dan pandangan negatif dari pasar. Hal ini sejalan dengan penelitian yang dilakukan oleh Kansal et al., (2014), Razak (2015), serta Urmila \& Mertha (2017) yang menyatakan bahwa profitabilitas berpengaruh positif pada pengungkapan CSR. Berdasarkan uraian maka hipotesisi yang diajukan dalam penelitian ini sebagai berikut.

$\mathrm{H}_{2}$ : Profitabilitas berpengaruh positif pada CSR Disclosure.

Perusahaan dengan likuiditas yang tinggi akan memberikan sinyal kepada perusahaan yang lain bahwa mereka lebih baik daripada perusahaan lain, dengana melakukan kegiatana yang berhubungan dengan lingkungan sosial. Sinyal yang diberikan berupa pengungkapan informasi tanggung jawab sosial perusahaan secara lebih luas. Perusahaan yang mempunyai level likuiditas tinggi menggambarkan kesuksesan perusahaan dalam memenuhi komitmen jangka pendeknya sesuai dengan waktu yang telah disepakati. Perusahaan yang memiliki kemampuan yang tinggi dalam melunasi kewajiban jangka pendeknya 
akan mengungkapkan tanggung jawab sosialnya karena perlu melakukan pengungkapan yang lebih rinci (Arif \& Wawo, 2016). Berdasarkan penjelasan tersebut, maka hipotesis yang ditetapkan dalam riset ini sebaai berikut.

$\mathrm{H}_{3}$ : Likuiditas berpengaruh positif pada CSR Disclosure.

\section{METODE PENELITIAN}

Lokasi penelitian dilakukan pada perusahaan terkategori high profile terdaftar di Bursa Efek Indonesia periode 2015-2018. Obyek dari penelitiani ini adalah CSR disclosure, ukuran perusahaan, profitabilitas, dan likuiditas. Variabel terikat dalam penelitian ini adalah CSR disclosure (Y) yang diproksikan dengan CSRDI (Corporate Social Responsibilty Disclosure Index). Variabel bebas dalam penelitian inii adalaha ukuran perusahaan $\left(X_{1}\right)$, profitabilitas $\left(X_{2}\right)$, dan likuiditas $\left(X_{3}\right)$.

CSRDI (Corporate Social Responsibilty Disclosure Index) CSR berdasarkan indikator Global Reporting Initiativeh (GRI) versi 4.0 hadalah proksi yang digunakan untuk mengukur pengungkapan CSR. Pengukuran tersebut menggunakan variabel dummy. Penelitian yang dilakukan oleh Urmila \& Mertha (2017) menjabarkan rumus perhitungan CSRDI sebagai berikut.

$\mathrm{CSRDI}_{\mathrm{j}}=\frac{\sum X_{i j}}{n_{j}}$

Dimana:

$\mathrm{CSRDI}_{\mathrm{j}} \quad=$ Corporate Social Responsibility Disclosure Indeks Perusahaan $\mathrm{j}$

$\mathrm{n}_{\mathrm{j}} \quad=$ jumlah item untuk perusahaan $\mathrm{j} ; \mathrm{nj}=91$

Xij $\quad=1=$ jika item diungkapkan; $0=$ jika item tidak diungkapkan

Variabel ukuran perusahaan diukur menggunakan log natural total aset. Rumus untuk perhitungan ukuran perusahaan dalam penelitian Dibia \& Onwuchekwa (2015) dapat dijabarkan sebagai berikut.

Size $=\log$ natural $($ Total Aktiva Perusahaan)

Profitabilitasi dihitung dengan menggunakan ROA (return on Asset). ROA adalah analisisi keuangan yang menunjukkan kemampuan perusahaan memperoleh laba atas total asset yang dimiliki. Penelitian yang dilakukan oleh Putri et al., (2017) menjabarkan rumus perhitungan untuk profitabilitas adalah:

ROA $=\frac{\text { LabaBersih setelah Pajak }}{\text { Total Aktiva }}$

Likuiditas adalah suatu kondisi yang menunjukkan kemampuan perusahaan dalam mendanai operasional perusahaan dan melunasi hutang jangka pendeknya. Perhitungan likuiditas yang digunakan dalam penelitian ini adalah rasio lancar (current ratio). Rumus perhitungan untuk likuiditas menurut Dewi \& Wirawati (2017) adalah:

Current Ratio $=\frac{\text { Aktiva Lancar }}{\text { Hutan } g \text { Lancar }}$

Populasi perusahaan highp profile didapat dari data yang ada di website Bursa Efek Indonesia tahun 2015-2018 yaitu sebanyak 271 perusahaan. Adapun teknik sampling yang digunakan adalah nonprobability isampling dengan teknik purposive sampling. 
Tabel 1. Proses Seleksi Sampel dengan Purposive Sampling

\begin{tabular}{clc}
\hline No. & \multicolumn{1}{c}{ Kriteria } & Jumlah \\
\hline 1 & $\begin{array}{l}\text { Perusahaan high profile yang terdaftar di Bursa Efek } \\
\text { Indonesia dan mempublikasikan laporan keuangan yang } \\
\text { lengkap dan terperinci untuk periode yang berakhir pada } \\
\text { tanggal 31 Desember 2015-2018 }\end{array}$ & 271 \\
$2 \quad \begin{array}{l}\text { Mengalami delisting selama periode pengamatan dan } \\
\text { memiliki laba bersih di bawah 0 atau negatif }\end{array}$ & $(190)$ \\
3 & $\begin{array}{l}\text { Perusahaan tidak menggunakan mata uang rupiah (Rp) } \\
\text { dalam laporan keuangan } \\
\text { Jumlah perusahaan yang digunakan sebagai sampel }\end{array}$ & 70 \\
$\quad$ Jumlah data observasi (4 tahun pengamatan)
\end{tabular}

Sumber: Data Penelitian, 2020

Analisis Regresi dilakukan untuk mengetahui hubungan antara satu atau beberapa variabel independent dengan sebuah variabel dependen. Secara matematis hubungan antara variabel independeni dan variabel idependen dapat dijabarkan sebagai berikut.

$Y=a+b_{1} X_{1}+b_{2} X_{2}+b_{3} X_{3}+b_{4} X_{4}+\varepsilon$

Keterangann:

Y : CSR Disclosure

$\mathrm{X}_{1}$ : Ukuran Perusahaan

$\mathrm{X}_{2} \quad$ : Profitabilitas

$\mathrm{X}_{3} \quad$ : Likuiditas

$\mathrm{X}_{4} \quad$ : Leverage

a : Intercept

b1 : Koefisien regresi variabel independen $X_{1}$

b2 : Koefisien regresi variabel independen $X_{2}$

b3 : Koefisien regresi variabel independen $X_{3}$

b4 : Koefisien regresi variabel independen $X_{4}$

$\varepsilon \quad$ : eror

\section{HASIL DAN PEMBAHASAN}

Statistik deskriptif memberikan informasi karakteristik variabel penelitian khususnyap terkaitp nilai minimum nilai maksimum, nilai rata-rata (mean) dan standar deviasi. Hasil dari analisis deskriptif penelitian dapat dilihat pada Tabel 2.

Tabel 2. Hasil Uji Statistik Deskriptif

\begin{tabular}{llllll}
\hline & $\mathrm{N}$ & Minimum & Maximum & Mean & $\begin{array}{l}\text { Std. } \\
\text { Deviation }\end{array}$ \\
\hline Ukuran Perusahaan & 280 & 24,899 & 32,000 & 28,66216 & 1,557747 \\
Profitabilitas & 280 & 0,001 & 1,218 & 0,09742 & 0,136857 \\
Likuiditas & 280 & 0,423 & 9,677 & 2,41237 & 1,746393 \\
CSR Disclosure & 280 & 0,033 & 0,604 & 0,23572 & 0,094089 \\
Valid N (listwise) & 280 & & & & \\
\hline
\end{tabular}

Sumber: Data Penelitian, 2020

Berdasarkan hasil uji statistic deskriptif Tabel 2, didapatkan informasi sebagai berikut. Variabel ukuran perusahaan memiliki 280 sampel penelitian. Variabeli ukuran perusahaan memiliki nilai minimum sebesar 24,899 yang 
berarti nilai terendah dari variabel ukuran perusahaan yaitu dari perusahaan PT. Pembangunan Graha Lestari, Tbk. (PGLI) tahun 2015. Nilai maksimum dari variabel ukuran perusahaan adalah sebesar 32,200 yang berarti nilai tertinggi dari variabel ukuran perusahaan yaitu dari perusahaan PT. Indofood Sukses Makmur, Tbk. (INDF) tahun 2018. Mean dari ukuran perusahaan sebesar 28,66216 artinya rata-rata ukuran perusahaan pada 280 sampel perusahaan terkategori high profile pada tahun 2015-2018 adalah 28,66216. Nilai simpangan baku atau standar deviasi sebesar 1,557747 lebih kecil dari nilai rata-rata mengindikasikan bahwa tidak terdapat fluktuasi yang tinggi pada ukuran perusahaan di perusahaan yang menjadi sampel.

Variabel profitabilitas yang diproksikan dengan Return on Asset memiliki 280 sampel penelitian. Variabel profitabilitas memiliki nilai minimum sebesar 0,001 yang berarti nilai terendah dari variabeli profitabilitas yaitu dari perusahaan PT. Steel Pipe Industry Indonesia, Tbk. (ISSP) tahun 2017. Nilai maksimum profitabilitas adalah sebesar 1,218 yang berarti nilai tertinggi dari variabel profitabilitas yaitu dari perusahaan PT. Ratu Prabu Energi, Tbk. (ARTI) tahun 2018. Mean dari variabel profitabilitas sebesar 0,09742 artinya rata-rata profitabilitas pada 280 sampel perusahaan pada tahun 2015-2018 adalah sebesar 0,09742. Standar deviasi sebesar 0,136857 lebih besar dari nilai rata-rata artinya terdapat fluktuasif yang cukup besar dari nilai profitabilitas di perusahaan sampel.

Variabel likuiditas yang diproksikan dengan Current Ratio memiliki 280 sampel penelitian. Variabel likuiditas memiliki nilai minimum sebesar 0,423 yang berartio nilai terendah dari variabel likuiditas yaitu dari perusahaan PT. Temas, Tbk. (TMAS) utahun 2016. Nilai mmaksimum variabel likuiditas adalah sebesar 9,677 yang berarti nilai tertinggi dari variabel likuiditas yaitu dari perusahaanh PT. Intanwijaya Internasional, Tbk. (INCI) tahunh 2015. Mean dari variabel likuiditas sebesar 2,41237 artinya rata-rata likuidita padal 280 sampel perusahaan pada tahun 2015-2018 adalah sebesar 2,41237. Standar deviasi sebesar 1,746393 lebih kecil dari nilai rata-rata artinya tidak terdapat fluktuasi yang cukup besar dari nilai likuiditas di perusahaane sampel.

Variabel CSR Disclosure yang diproksikan dengan Corporate Social Disclosure Index (CSRDI) memiliki 280 sampel penelitian. Variabel CSR Disclosure memiliki nilai minimum sebesar 0,033 yang berarti nilai terendah dari variabel CSR Disclosure yaitu dari perusahaan PT. Pelayaran Nelly Dwi Putri, Tbk. (NELY) tahun 2017. Nilai maksimum variabel CSR Disclosure adalah sebesar 0,604 yang berarti nilai tertinggi dari variabel likuiditas yaitu dari perusahaan PT. Timah, Tbk. (TINS) tahun 2016. Mean dari variabel CSR Disclosure sebesar 0,23572 artinya rata-rata nilai CSR Disclosure pada 280 sampel perusahaan pada tahun 2015-2018 adalah sebesar 0,23572. Standar deviasi sebesar 0,094089 lebih kecil dari nilai rata-rata artinya tidak terdapat fluktuasi yang cukup besar dari nilai CSR Disclosure di perusahaan sampel.

Penelitian ini menggunakan analisis regresi linear berganda untuk menganalisis pengaruh Ukuran Perusahaan $\left(X_{1}\right)$, Profitabilitas $\left(X_{2}\right)$, dan Likuiditas $\left(\mathrm{X}_{3}\right)$ pada Corporate Social Responsibility (CSR) Disclosurec (Y). Analisis Regresi Lineara Berganda diolah dengan bantuan software SPSS for Windows dengan hasil yang diperoleh sebagaif tberikut. 
Tabel 3. Hasil Analisis Regresi Linear Berganda

\begin{tabular}{|c|c|c|c|c|c|c|}
\hline \multirow[b]{2}{*}{ Model } & & \multicolumn{2}{|c|}{$\begin{array}{l}\text { Unstandardized } \\
\text { Coefficients }\end{array}$} & \multirow{2}{*}{$\begin{array}{l}\text { Standardized } \\
\text { Scoefficients } \\
\text { Beta }\end{array}$} & \multirow[b]{2}{*}{$t$} & \multirow[b]{2}{*}{ Sig. } \\
\hline & & $\mathrm{B}$ & Std. Error & & & \\
\hline \multirow[t]{8}{*}{1} & (Constant) & $-0,407$ & 0,098 & & $-4,153$ & 0,000 \\
\hline & $\begin{array}{l}\text { Ukuran } \\
\text { Perusahaan }\end{array}$ & 0,023 & 0,003 & 0,379 & 6,786 & 0,000 \\
\hline & Profitabilitas & $-0,051$ & 0,039 & $-0,074$ & $-1,306$ & 0,193 \\
\hline & Likuiditas & $-0,003$ & 0,003 & $-0,064$ & $-1,108$ & 0,269 \\
\hline & $R^{2}$ & 0,161 & & & & \\
\hline & Adjusted $R^{2}$ & 0,151 & & & & \\
\hline & Fhitung & 17,599 & & & & \\
\hline & Sig. F & 0,000 & & & & \\
\hline
\end{tabular}

Sumber: Data Penelitian, 2020

Berdasarkan hasil analisis regresi linear berganda pada tabel 3 tersebut, maka dapat dibuat persamaan sebagai berikut.

$$
\text { CSRDI }=-0,407+0,023 X_{1}-0,051 X_{2}-0,003 X_{3}+\varepsilon
$$

Berdasarkan persamaan di atas, dapat dijelaskan bahwa nilai konstanta (a) -0,407 menunjukkan bahwa apabila Ukuran Perusahaan $\left(X_{1}\right)$, Profitabilitas $\left(\mathrm{X}_{2}\right)$, Odan Likuiditas $\left(\mathrm{X}_{3}\right)$ sama dengan 0 (nol), maka nilai CSR Disclosure $(\mathrm{Y})$ akan menurun sebesar 0,407 .

Nilai koefisien regresi variabel Iukuran perusahaan $=\mathrm{P} 0,023$ menunjukkan bahwa jika nilai Ukuran Perusahaan $\left(X_{1}\right)$ naik 1\% (satu persen) maka nilai CSR Disclosure (Y) akan meningkat sebesar 0,023 persen dengan asumsi variabelPlainnya konstan.

Besarnya adjusted $R^{2}$ (koefisien determinasi yang telah disesuaikan) pada model regresi yang digunakan adalah sebesar 0,15. Ini berarti bahwa setiap 15 persen variasi dari variabel dependen, yaitu CSR Disclosure dipengaruhi oleh variasi dari variabel independent yaitu Ukuran Perusahaan, Profitabilitas, dan Likuiditas, sedangkan sisanya sebesar 85 persen dipengaruhi oleh faktor-faktor lain yang tidak dimasukkan dalam modelregresi.

Hasil uji kelayakan rmodel (uji F) pada model regresi yang digunakan menunjukkan bahwa nilai $\mathrm{F}$ hitung sebesar 17,599 dengan nilai Signifikansi $\mathrm{p}$ value 0,000 yang lebih kecil dari $a=0,05$. Hal ini berarti model yang digunakan pada penelitian inin adalah layak. Hasil ini memberikan makna bahwa ketiga variabel mampu memprediksi atau menjelaskan fenomena CSR Disclosure pada perusahaan terkategorih high profile yang terdaftar di Bursa Efek Indonesia tahun 2015-2018. Hal ini berarti secara simultan ukuran perusahaan $\left(X_{1}\right)$, profitabilitas $\left(\mathrm{X}_{2}\right)$, dan likuiditas $\left(\mathrm{X}_{3}\right)$ berpengaruh signifikan terhadap CSR Disclosure.

Hipotesis pertama penelitian ini menyatakan bahwa ukuran perusahaan berpengaruh positif pada CSR Disclosure. Pengujian yang dilakukan dalam penelitian ini memperoleh hasil nilai koefisien regresi untuk variabel ukuran perusahaan sebesar 0,023 dengan tingkat signifikansi sebesar 0,000 lebih kecil dibanding taraf signifikansi 0,05. Hasil ini menunjukkan bahwa ukuran perusahaan berpengaruh positif signifikan pada CSR Disclosure perusahaan terkategori high profile yang terdaftar di Bursa Efek Indonesia tahun 2015-2018, sehingga hipotesis pertama diterima. Hal ini menunjukkan bahwa ukuran 
perusahaan yang diukur dengan Ln Total Aktiva Perusahaan mampu memengaruhi kemampuan perusahaan untuk melaksanakan CSR Disclosure.

Perusahaan dengan ukuran besar akan lebih menarik perhatian para stakeholder dibanding perusahaan kecil. Salah satu cara yang digunakan untuk menunjukkan performa untuk mendapatkan legitimasi tersebut adalah dengan lebihh memerhatikan kondisi lingkungan alam dan ssosial di sekitar perusahaan. Hasili penelitian ini sejalan dengan penelitian yang dilakukani oleh Razak (2015), Indraswari \& Astika (2015) serta Trencansky et al., (2014) yang menunjukkan bahwa ukuran perusahaan berpengaruh positif padah pengungkapan CSR.

Hipotesis kedua penelitian ini menyatakan bahwa profitabilitas berpengaruh positif pada CSR Disclosure. Pengujian yang dilakukan dalam penelitian ini memperoleh nilai koefisieni regresi untuk variabel profitabilita ssebesar -0,051 dengan tingkat signifikansi sebesar 0,193 lebih besar disbanding taraf signifikansi 0,05. Hasil ini menunjukkan bahwa profitabilitas tidak berpengaruh pada CSR Disclosure perusahaan terkategori high profile yang terdaftar di Bursa Efek Indonesia tahun 2015-2018, sehingga hipotesis kedua ditolak. Hal ini menunjukkan bahwa profitabilitas (ROA) tidak mampu memengaruhi kemampuan perusahaan untuk melaksanakan CSR Disclosure.

Teori stakeholder menjelaskan bahwa perusahaan memiliki kewajiban tanggung jawab sosial yang mengharuskan perusahaan untuk mempertimbangkan kepentingan semua pihak yang terkena dampak dari aktivitasnya. Perusahaan secara tidak langsung dipaksa oleh pemegang saham dan masyarakat untuk melakukan dan mengungkapkan kegiatan CSR, tanpa memandang apa pun status keuangan perusahaan tersebut. UU No. 40 Tahun 2007 pasal 74 ayat (3) mengatur pula bahwa perseroan yang tidak melaksanakan kewajiban tanggung jawab sosial tersebut dapat dipidana. Hasil penelitiana inii mendukung 'hasil' penelitian yang dilakukan oleh Wuttichindanon (2017) menyatakan bahwa pengungkapan CSR dilakukan oleh perusahaan atas pengaruh pemangku kepentingan, bukan berdasarkan tingkat profitabilitas, serta penelitian yang dilakukan oleh Chek et al., (2013) yang dalam penelitiannya justru mengungkapkan bahwa profitabilitas yang diproksikan dengan Return On Asset (ROA) hampir tidak berpengaruh pada pengungkapan WCSR. (Issa, 2017)

Hipotesis ketiga penelitian ini menyatakan bahwa likuiditas berpengaruh positifl pada CSR Disclosure. Pengujian yang dilakukan dalam penelitian ini memperoleh hasil nilai koefisien regresi untuk variabel likuiditas sebesar -0,003 dengan tingkat signifikansi sebesar 0,269 lebih besar dibanding taraf signifikansi 0,05. Hasil ini menunjukkan bahwa likuiditas tidak berpengaruh pada CSR Disclosure perusahaan terkategori high profile yang terdaftar di Bursa Efek Indonesia tahun 2015-2018, sehingga hipotesis ketiga ditolak. Hal ini menunjukkan bahwa likuiditas yang diukur dengan Current Ratio tidak mampu memengaruhi kemampuan perusahaan untuk melaksanakan CSR Disclosure. Lund-Thomsen et al. (2016)

Hasil penelitian ini menunjukkan bahwa perusahaan tidak melihat seberapa besar tingkat likuiditas ketika. melakukan CSR Disclosure. Regulasi yang telah diatur oleh pemerintah dalam aspek kegiatan tanggung jawab sosial perusahaan juga mendorong perusahaan untuk mengungkapkan CSR dalam setiap annual report sehingga perusahaan akan tetap melaksanakan CSR 
Disclosure dalam keadaan likuiditas yang haman maupun berisiko. Hal ini berarti mendukung teori stakeholder yang menyatakan bahwa manajemen organisasi diharapkan untuk melakukan aktivitas yang dianggap penting oleh stakeholdernya dan melaporkan kembali aktivitas tersebut kepada stakeholder. Pengungkapan CSR yang dilaksanakan perusahaan memungkinkan adanya evaluasi dari stakeholder atas kegiatan tanggung jawab sosial yang dilakukan oleh perusahaan. Hasil penelitian kini mendukung hasil penelitian yang dilakukan oleh Rokhman (2015) dan Agustin, (2018) yang menyatakan bahwa likuiditas tidak berpengaru pada pengungkapan CSR.

\section{SIMPULAN}

Ukuran perusahaan berpengaruh positif dan signifikan pada CSR Disclosure perusahaan terkategori high profile yang terdaftar di Bursa Efek Indonesia tahun 2015-2018. Berdasarkan teoris legitimasi, hal ini menunjukkan bahwa perusahaan besar akan mengungkapkan tanggung jawab sosial untuk mendapatkan legitimasi dari stakeholder, karena semakin besar perusahaan maka tuntutan stakeholder atas manfaat keberadaan perusahaan tersebut cenderung lebih besar. Profitabilitas tidak berpengaruh pada CSR Disclosure perusahaan terkategori high profile yang terdaftar di Bursa Efek Indonesia tahun 2015-2018. Hal dini menunjukkan bahwa perusahaan wajib untuk melaksanakan dan mengungkapkan program CSR-nya tanpa memerhatikan kondisi keuangan perusahaan karena adanya aturan yuridis yang mengikat perusahaan. Likuiditas tidak berpengaruh pada CSR Disclosure perusahaan terkategori high profile yang terdaftar di Bursa Efek Indonesia tahun 2015-2018. Regulasi yang telah diatur oleh pemerintah dalam aspek kegiatan tanggung jawab sosial perusahaan juga mendorong perusahaan untuk mengungkapkan CSR dalam setiap annual report sehingga perusahaan akan tetap melaksanakan CSR Disclosure dalam keadaan likuiditas yang aman maupun berisiko, (Nega, 2017).

Perusahaan dalam pelaksanaan CSR sebaiknya memerhatikan aspek keseimbangan di setiap program yang akan dijalankan. Program CSR yang dilaksanakan harus mencakup seluruh komponen, baik itu sumber daya manusia yang ada dalam perusahaan mapun masyarakat dan lingkungan sosial dan alam. Program CSR yang adilaksanakan perusahaan besar sebaiknya lebih banyak dan berdampak signifikan bagi stakeholder yang mengharapkan perusahaan berperan aktif dalam usaha kesejahteraan sosial. Pelaksanaan CSR oleh perusahaan harus memerhatikan aspek going concern, agar menjamin kepercayaan investor dan calon investor untuk menanamkan modal dalam perusahaan. Aspek going concern menjadi penting ketika perusahaan ingin menarik investor karena aspek ini menjadi salah satu tolak ukur kepercayaan investor pada perusahaan, (Bani-Khalid et al., 2017).

Setiap perusahaan, utamanya perusahaan go public wajib melaksanakan program CSR dan melaporkannya di dalam annual report tanpa mementingkan bagaimana kondisi keuangan perusahaan karena telah ada regulasi yang mewajibkan perusahaan untuk melaksanakan dan mengungkapkan CSR. Pihak regulator, yaitu pemerintah sebaiknya menetapkan poin-poin yang lebih rinci yang harus dilaksanakan dan diungkapkan oleh perusahaan dalam kegiatan CSR 
yang dilaksanakan, sehingga dapat mewujudkan keseimbangan dan pemerataan

kesejahteraan menjadi lebih mungkin untuk dicapai, (Mamun et al., 2017).

\section{REFERENSI}

Agustin, D. (2018). Pengaruh Likuiditas dan Ukuran Perusahaan terhadap Pengungkapan CSR dengan Profitabilitas sebagai Variabel Moderasi. Eprints.Perbanas. $\quad$ http://eprints.perbanas.ac.id/3755/8/ARTIKEL ILMIAH.pdf

Arif, F. A., \& Wawo, A. (2016). Pengaruh Ukuran Perusahaan, Leverage, Dan Likuiditas Terhadap Pengungkapan Corporate Social Responsibility Dengan Profitabilitas Sebagai Variabel Moderasi. Assets, 6(2), 177-195.

Arika, N. L. P. F. W. A., \& Sudana, I. P. (2017). Industry Profile Dan Corporate Social Responsibility Expenditure. E-Jurnal Akuntansi Universitas Udayana, 19(2), 1551-1578.

Bani-Khalid, T., Kouhy, R., \& Hassan, A. (2017). The Impact of Corporate Characteristics on Social and Environmental Disclosure (CSED): The Case of Jordan. Journal of Accounting and Auditing: Research \& Practice, 2017, 1-29. https:// doi.org/10.5171/2017.369352

Peraturan No. X.K.6: Penyampaian Laporan Tahunan Emiten atau Perusahaan Publik, (2012).

Bulan, A., \& Astika, I. (2014). Moderasi Corporate Social Responsibility terhadap Pengaruh Kinerja Keuangan Pada Nilai Perusahaan. E-Jurnal Akuntansi Universitas Udayana, 8(2), 136-152.

Caulkins, D., Evans, B., Liang, C., \& Chaet, J. (2013). President Howard Bowen E Corporate Social Responsibility. Grinnell.Edu/News. https://www.grinnell.edu/news/ president-howard-bowen-corporatesocial-responsibility

Dewi, I. A. A. W., \& Wirawati, N. G. P. (2017). Pengaruh Agresivitas Pajak Pada Corporate Social Responsibility Dengan Likuiditas Sebagai Variabel Pemoderasi. E-Jurnal Akuntansi Universitas Udayana, 19(3), 1943-1969. https:// doi.org/ISSN : 2302-8556

Dibia, N. O., \& Onwuchekwa, J. C. (2015). Determinants of Environmental Disclosures in Nigeria: A Case Study of Oil and Gas Companies. International Journal of Finance and Accounting, 4(3), 145-152. https://doi.org/10.5923/j.ijfa.20150403.01

Dyduch, J., \& Krasodomska, J. (2017). Determinants of corporate social responsibility disclosure: An empirical study of Polish listed companies. Sustainability (Switzerland), 9(11). https:/ / doi.org/10.3390/su9111934

Howard Bowen. (1953). Social Responsibilities of the Businessman (1953). In Social Responsibilities of the Businessman (1953). University of Iowa Press. https:// doi.org/10.2307/j.ctt20q1w8f

Indraswari, G. A. D., \& Astika, I. B. P. (2015). Pengaruh Profitabilitas, Ukuran Perusahaan, dan Kepemilikan Saham Publik terhadap Pengungkapan CSR. E-Jurnal Akuntansi Universitas Udayana, 11(1), 289-302. https:/ / doi.org/10.1136/annrheumdis-2017-eular.3008

Issa, A. I. F. (2017). The Factors Influencing Corporate Social Responsibility Disclosure in the Kingdom of Saudi Arabia. Australian Journal of Basic and 
Applied Sciences, 11(July), 1-19.

Kansal, M., Joshi, M., \& Batra, G. S. (2014). Determinants of corporate social responsibility disclosures: Evidence from India. Advances in Accounting, 30(1), 217-229. https://doi.org/10.1016/j.adiac.2014.03.009

Lund-Thomsen, P., Lindgreen, A., \& Vanhamme, J. (2016). Industrial Clusters and Corporate Social Responsibility in Developing Countries: What We Know, What We do not Know, and What We Need to Know. Journal of Business Ethics, 133(1), 9-24. https://doi.org/10.1007/s10551-014-2372-8

Mamun, M. A., Shaikh, J. M., \& Easmin, R. (2017). Corporate Social Responsibility Disclosure in Malaysian Business. Academy of Strategic Management Journal, 16(2), 29-47.

Mandaika, Y., \& Salim, H. (2015). Pengaruh Ukuran Perusahaan, Kinerja Keuangan, Tipe Industri, dan Financial Leverage Terhadap Pengungkapan Corporate Social Responsibility: Studi Empiris pada Perusahaan Manufaktur yang Terdaftar di Bursa Efek Indonesia Tahun 2011-2013. Jurnal Akuntansi, 8(2), 181-201. https:// doi.org/10.25170/jara.v8i2.18

Mudjiyanti, R., \& Maulani, S. S. (2017). Pengaruh Likuiditas dan Profitabilitas terhadap Pengungkapan Corporate Social Responsibility pada Perusahaan Terdaftar di Bursa Efek Indonesia. Jurnal Manajemen Dan Bisnis MEDIA EKONOMI, XVII(1), 7-12.

Nega, F. T. (2017). The Relationship between Financial Performance, Firm Size, Leverage and Corporate Social Responsibility. ProQuest Dissertations and Theses, 164. http:/ / ezphost.dur.ac.uk/login?url=https:// search.proquest.com/docview /1981955154?accountid=14533\%0Ahttp:/ /openurl.ac.uk/ukfed:dur.ac.uk?g enre $=$ dissertations $+\% 26+$ theses \&issn $=\&$ title $=\mathrm{The}+$ Relationship + between $+\mathrm{Fi}$ nancial+Performance $\% 2 C+$ Firm+Size $\% 2 C+$ Leverage+and

Ni Luh Putu Wiagustini. (2014). Manajemen Keuangan (Jiwa Atmaja (ed.)). Udayana University Press.

Purwanto, A. (2011). Pengaruh Tipe Industri, Ukuran Perusahaan, Profitabilitas. Jurnal Akuntansi Dan Auditing, 8(1), 12-29.

Putri, R. K., Zulbahridar, \& Kurnia, P. (2017). Pengaruh Ukuran Perusahaan, Profitabilitas, Leverage, Likuiditas, Dan Basis Kepemilikan Terhadap Corporate Social Responsibility Pada Perusahaan Pertambangan Yang Terdaftar Di Bursa Efek Indonesia (Bei) Periode Tahun 2012-2014. Jurnal Online Mahasiswa Fakultas Ekonomi Universitas Riau, 4(1), 558-571.

Razak, R. A. (2015). Corporate Social Responsibility Disclosure and its Determinants in Saudi Arabia. Middle-East Journal of Scientific Research, 23(10), 2388-2398. https:// doi.org/10.5829/idosi.mejsr.2015.23.10.22768

Roberts, R. W. (1992). Determinants of Corporate Social Responsibility Disclosure: An Application of Stakeholder Theory. Accounting, Organizations and Society, 17(6), 595-612. https:// doi.org/10.1016/0361-3682(92)90015-K

Rokhman, M. T. N. (2015). Pengaruh Size, Profitabilitas, dan Likuiditas Terhadap Corporate Social Responsibility (CSR) (Studi Empiris pada Perusahaan LQ45 yang Terdaftar di BEI). Jurnal Ilmiah - Vidya, 25(2), 195-203.

Tamby Chek, I., Zuriyati Bt Mohamad, Z., Yunus, N., \& Mat Norwani, N. (2013). Corporate Social Responsibility (CSR) Disclosure in Consumer Products and 
Plantation Industry in Malaysia. American International Journal of Contemporary Research, 3(5), 118-125.

Trencansky, D., Tsaparlidis, D., \& Ittonen, K. (2014). The Effects of Company's Age, Size and Type of Industry on the Level of CSR. Umea School of Business and Economics, 1-81. http://www.divaportal.org/smash/get/diva2:757602/FULLTEXT01.pdf

Urmila, N. M. D., \& Mertha, M. (2017). Tipe Perusahaan Memoderasi Ukuret an Perusahaan, Profitabilitas, Kepemilikan Asing pada Pengungkapan CSR Perusahaan Manufaktur di BEI. E-Jurnal Akuntansi Universitas Udayana, 19(3), 2145-2174.

Widiastuti, H., Utami, E. R., \& Handoko, R. (2018). Pengaruh Ukuran Perusahaan, Tipe Industri, Growth, dan Media Exposure terhadap Pengungkapan Tanggung Jawab Sosial Perusahaan (Studi Empiris pada Perusahaan yang Terdaftar di Bursa Efek Indonesia Tahun 2014-2015). Riset Akuntansi Dan Keuangan Indonesia, 3(2), 107-117. https:// doi.org/10.23917/reaksi.v3i2.6745

Wuttichindanon, S. (2017). Corporate social responsibility disclosure-choices of report and its determinants: Empirical evidence from firms listed on the Stock Exchange of Thailand. Kasetsart Journal of Social Sciences, 38(2), 156162. https://doi.org/10.1016/j.kjss.2016.07.002 